\title{
Cisplatin and carboplatin result in similar gonadotoxicity in immature human testis with implications for fertility preservation in childhood cancer
}

Melissa D. Tharmalingam ${ }^{1,2 \dagger}$, Gabriele Matilionyte ${ }^{1 \dagger}$, William H. B. Wallace ${ }^{3}$, Jan-Bernd Stukenborg ${ }^{4}$, Kirsi Jahnukainen ${ }^{4,5}$, Elizabeth Oliver ${ }^{4}$, Anne Goriely ${ }^{6}$, Sheila Lane ${ }^{7}$, Jingtao Guo ${ }^{8,9}$, Bradley Cairns ${ }^{9}$, Anne Jorgensen ${ }^{10}$, Caroline M. Allen ${ }^{11}$, Federica Lopes ${ }^{1}$, Richard A. Anderson ${ }^{1}$, Norah Spears ${ }^{11}$ and Rod T. Mitchell ${ }^{1,3^{*}}$

\begin{abstract}
Background: Clinical studies indicate chemotherapy agents used in childhood cancer treatment regimens may impact future fertility. However, effects of individual agents on prepubertal human testis, necessary to identify later risk, have not been determined. The study aimed to investigate the impact of cisplatin, commonly used in childhood cancer, on immature (foetal and prepubertal) human testicular tissues. Comparison was made with carboplatin, which is used as an alternative to cisplatin in order to reduce toxicity in healthy tissues.

Methods: We developed an organotypic culture system combined with xenografting to determine the effect of clinically-relevant exposure to platinum-based chemotherapeutics on human testis. Human foetal and prepubertal testicular tissues were cultured and exposed to cisplatin, carboplatin or vehicle for $24 \mathrm{~h}$, followed by $24-240 \mathrm{~h}$ in culture or long-term xenografting. Survival, proliferation and apoptosis of prepubertal germ stem cell populations (gonocytes and spermatogonia), critical for sperm production in adulthood, were quantified.

Results: Cisplatin exposure resulted in a significant reduction in the total number of germ cells $(-44 \%, p<0.0001)$ in human foetal testis, which involved an initial loss of gonocytes followed by a significant reduction in spermatogonia. This coincided with a reduction $(-70 \%, p<0.05)$ in germ cell proliferation. Cisplatin exposure resulted in similar effects on total germ cell number (including spermatogonial stem cells) in prepubertal human testicular tissues, demonstrating direct relevance to childhood cancer patients. Xenografting of cisplatin-exposed human foetal testicular tissue demonstrated that germ cell loss $(-42 \%, p<0.01)$ persisted at 12 weeks. Comparison (Continued on next page)
\end{abstract}

\footnotetext{
* Correspondence: rod.mitchell@ed.ac.uk

${ }^{+}$Melissa D. Tharmalingam and Gabriele Matilionyte contributed equally to this work.

'MRC Centre for Reproductive Health, The Queen's Medical Research

Institute, The University of Edinburgh, 47 Little France Crescent, Edinburgh EH16 4TJ, Scotland, UK

${ }^{3}$ Edinburgh Royal Hospital for Sick Children, 9 Sciennes Road, Edinburgh EH9

$1 \mathrm{LF}$, Scotland, UK

Full list of author information is available at the end of the article
}

(c) The Author(s). 2020 Open Access This article is licensed under a Creative Commons Attribution 4.0 International License, which permits use, sharing, adaptation, distribution and reproduction in any medium or format, as long as you give appropriate credit to the original author(s) and the source, provide a link to the Creative Commons licence, and indicate if changes were made. The images or other third party material in this article are included in the article's Creative Commons licence, unless indicated otherwise in a credit line to the material. If material is not included in the article's Creative Commons licence and your intended use is not permitted by statutory regulation or exceeds the permitted use, you will need to obtain permission directly from the copyright holder. To view a copy of this licence, visit http://creativecommons.org/licenses/by/4.0/. The Creative Commons Public Domain Dedication waiver (http://creativecommons.org/publicdomain/zero/1.0/) applies to the data made available in this article, unless otherwise stated in a credit line to the data. 


\begin{abstract}
(Continued from previous page)
between exposures to human-relevant concentrations of cisplatin and carboplatin revealed a very similar degree of germ cell loss at $240 \mathrm{~h}$ post-exposure.

Conclusions: This is the first demonstration of direct effects of chemotherapy exposure on germ cell populations in human foetal and prepubertal testis, demonstrating platinum-induced loss of all germ cell populations, and similar effects of cisplatin or carboplatin. Furthermore, these experimental approaches can be used to determine the effects of established and novel cancer therapies on the developing testis that will inform fertility counselling and development of strategies to preserve fertility in children with cancer.
\end{abstract}

Keywords: Human, Testis, Cisplatin, Germ cell, Fertility, Prepubertal, Foetal, Xenograft

\section{Background}

Survival rates for children with cancer have increased dramatically over recent decades, and currently, more than $80 \%$ of those affected are expected to survive their disease into adulthood [1]. However, the long-term impacts of cancer treatment remain a major concern for this patient population. The mainstay of cancer treatment includes chemotherapy and radiotherapy, both of which have the potential to damage healthy tissues resulting in significant long-term morbidity [2]. An association between chemotherapy exposure and effects on the reproductive system in male and female childhood cancer survivors is well-recognised and this may result in infertility in adulthood [3, 4]. Alkylating agents (e.g. cyclophosphamide and procarbazine) are reported to be amongst the most highly gonadotoxic chemotherapeutic compounds in both males and females, and cumulative exposure to these agents can be used to estimate the risk of gonadal damage in patients due to receive such therapies [5]. However, these models do not include nonalkylating agents that may also contribute to gonadotoxicity, nor are they able to determine the direct effects of chemotherapeutic agents on the gonad.

Major differences exist between the prepubertal and adult testis in humans, especially in terms of germ cell populations [6]. Spermatogenesis does not start until after puberty and therefore sperm are not present. The germ cell populations in the prepubertal testis are predominantly spermatogonia, expressing MAGEA4 protein. This includes a sub-population of spermatogonial stem cells (SSC), which express UTF1 [7, 8]. In human foetal and infantile testis, an additional population of undifferentiated germ cells (gonocytes), which express $\mathrm{AP} 2 \gamma$, are present. Gonocytes differentiate into (pre)spermatogonia over the course of foetal and early postnatal life [6]. Therefore, future fertility is dependent on differentiation from gonocyte to spermatogonia in infancy and subsequent survival of the SSC population during childhood.

Platinum-based chemotherapeutic drugs are widely used in paediatric oncology for the treatment of solid tumours including neuroblastoma, germ cell tumours and osteosarcoma $[5,9,10]$. These agents are considered to be cell-cycle independent and act to form DNA adducts, which elicit apoptosis and cell death [11]. Cisplatin is the most frequently used platinum-based compound, whilst carboplatin may be used as an alternative to cisplatin as it is considered to have a lower risk of ototoxicity and nephrotoxicity [12], although relative gonadotoxicity remains to be determined.

No previous studies have been conducted to test the effects of platinum-based chemotherapy on human testicular tissues. However, experimental systems have recently been developed to assess the direct impact of pharmaceuticals on immature human testicular tissues including short- (in vitro) and long-term (testicular xenograft) effects of acute exposure [13, 14]. These experimental approaches utilise human foetal testis, which contain the major germ cell populations of the childhood testis (gonocytes and spermatogonia), and can therefore be used to model the acute effects of chemotherapy exposure and potential for recovery of immature human testicular tissue.

In the present study, we aimed to determine the effects of exposure to clinically-relevant concentrations of platinum-based chemotherapy on germ cells of the immature prepubertal human testis using human foetal and prepubertal tissues. We also aimed to investigate the relative gonadotoxicity of cisplatin compared to that of carboplatin.

\section{Methods}

\section{Experimental design}

Given that childhood cancer survivors are reported to have lower fertility rates in adulthood, we aimed to understand the effects of exposure to platinum-based chemotherapy agents (cisplatin and carboplatin) on key germ cell populations in immature human testis. We performed controlled laboratory experiments using both in vitro (short-term) and xenograft (long-term) models (Fig. 1). Experimental protocols were designed prior start of experiments. Immature human testicular tissue pieces were exposed to clinically relevant chemotherapy doses based on human plasma serum levels obtained from 


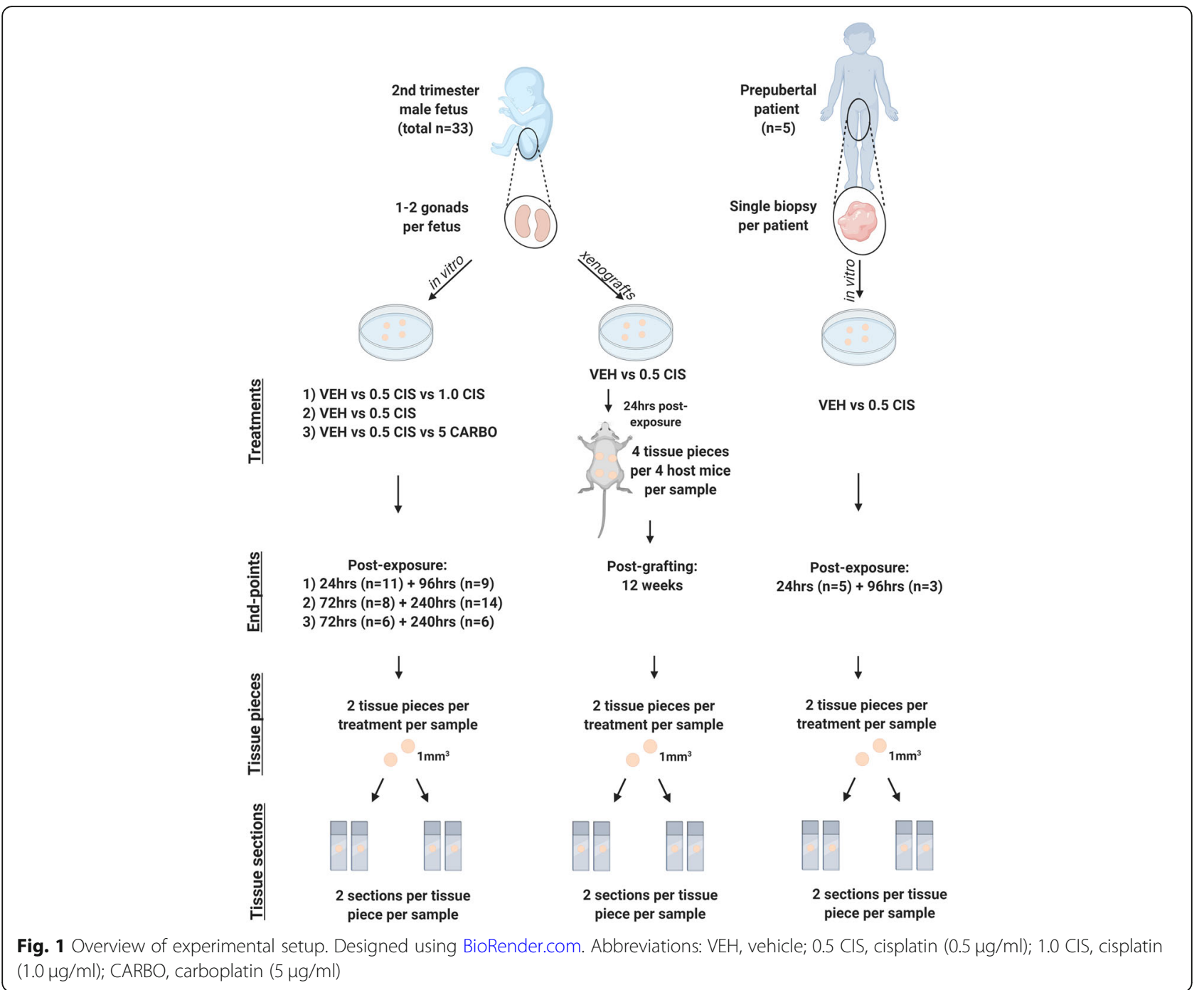

paediatric cancer patients. Sample size was determined based on previous studies using human tissue (at least $n=5$ for each experiment).

Initial experiments using human foetal tissues investigated the effects of cisplatin-exposure on germ cells using two drug concentrations $(0.5$ and $1.0 \mu \mathrm{g} / \mathrm{ml})$ and two time-points post-exposure ( 24 and $96 \mathrm{~h}$ ). Further experiments were performed to determine the germ cell effects of cisplatin-exposure $(0.5 \mu \mathrm{g} / \mathrm{ml}$ only) at intermediate $(72 \mathrm{~h})$ and long-term $(240 \mathrm{~h})$ time-points. Some of the in vitro cultured tissue pieces were randomly selected at $24 \mathrm{~h}$ post-exposure and subsequently xenografted for 12 weeks. Reciprocal grafts of control- or cisplatin-exposed tissue were grafted into the right and left dorsal flank of the same mouse, respectively. In addition, a comparison between exposure to cisplatin $(0.5 \mu \mathrm{g} / \mathrm{ml})$ and therapeutic equivalent concentrations of carboplatin $(5 \mu \mathrm{g} / \mathrm{ml})$ was investigated at 72 and $240 \mathrm{~h}$ post-exposure. Due to the limited amount of available tissue, the effects of cisplatin-exposure on germ cells in prepubertal human testicular tissue were investigated using a single concentration of cisplatin $(0.5 \mu \mathrm{g} / \mathrm{ml})$ at two time-points post-exposure ( 24 and $96 \mathrm{~h}$ ).

All data were analysed once the study was completed and no outliers were excluded. To compare the effect of treatment versus vehicle controls, we analysed at least two tissue sections from two replicates for each treatment. Endpoints included the quantification of key germ cell populations and assessment of proliferation and apoptosis. Investigators performing the quantification were blinded to the treatment group.

\section{Study approval}

Ethical approval for use of human foetal tissues for research was obtained from the South East Scotland Research Ethics Committee (LREC08/S1101/1), NRES committee North East - Newcastle and North Tyneside $1(08 / \mathrm{H} 0906 / 21+5)$ and NRES Committee London - 
Fulham (18/10/0822), and written informed consent was given by the women. Ethical approval for collection and use of human prepubertal testis tissues in research was obtained from the South East Scotland Research Ethics Committee (13/SS0145) and Oxford University Hospitals NHS Foundation Trust (2016/0140). Written informed consent was obtained from patients' parents/guardians and/or the patient themselves (where appropriate).

For studies involving animals, specific approval, including ethical approval, was given by the UK Home Office. All procedures carried out were by the University of Edinburgh Bioresearch and Veterinary Services and performed in accordance with the Animal (Scientific procedures) Act 1986.

\section{Tissue collection}

\section{Human foetal testicular tissues}

Testes from second-trimester human foetuses (14-22 weeks gestation; total $n=33$ ) were obtained after medical and surgical termination of pregnancy as described previously [6]. None of the terminations were due to foetal abnormalities. Ultrasound scan and subsequent direct measurement of foot length were used to determine gestational age. Sex was determined by PCR for the male-specific gene $S R Y$.

For studies involving animals, specific approval, including ethical approval, was given by the UK Home Office and all procedures carried out were in accordance with the Animal (Scientific procedures) Act 1986.

\section{Prepubertal human testicular tissues}

Prepubertal testicular tissues ( $n=5$ patients; aged $1,1,8$, 11 and 12 years) were obtained from chemotherapynaïve patients undergoing a testicular biopsy for fertility preservation at the Royal Hospital for Sick Children in Edinburgh and John Radcliffe Hospital in Oxford. A small portion $(\sim 10 \%)$ of the biopsy was donated for research purposes. Testicular tissues from Edinburgh were collected and immediately transported in Nutristem ${ }^{\circ}$ hSEC XF Medium (Biological industries) supplemented with $1 \%$ penicillin/streptomycin (Sigma-Aldrich). Testicular biopsies from Oxford were transported overnight in Hank's Balanced Salt solution (HBSS) with 10\% human serum albumin.

\section{Hanging drop culture system}

Human foetal and prepubertal tissue was utilised for in vitro experiments in a hanging drop culture system [15]. Testicular tissue was cut into small pieces $(\sim 1$ $\mathrm{mm}^{3}$ ) and placed into $30 \mu \mathrm{l}$ droplets of appropriate media (for foetal tissue: Alpha MEM (Lonza); 10\% foetal bovine serum, $1 \%$ penicillin/streptomycin, $1 \%$ nonessential amino acids, $2 \mathrm{mM} \mathrm{L}$-glutamine, $2 \mathrm{mM}$ sodium pyruvate and $1 \%$ insulin transferrin selenium (ITS) (all
Sigma-Aldrich); for prepubertal tissue: Alpha MEM (Lonza) and 10\% Knockout Serum Replacement (KSR; Gibco)) and cultured at $37^{\circ} \mathrm{C}$ and $32^{\circ} \mathrm{C}$, respectively, under $5 \% \mathrm{CO}_{2}$. Tissue pieces were cultured for 1-3 days (subject to the exact timing of the tissue arrival) prior to exposure to cisplatin (Sigma-Aldrich) or vehicle control $\left(\mathrm{ddH}_{2} \mathrm{O}\right)$ for $24 \mathrm{~h}$. Tissue pieces were then transferred to fresh media without cisplatin and cultured until 24, 72, 96 and $240 \mathrm{~h}$ post-cisplatin exposure. In a separate set of culture experiments, tissues were exposed for $24 \mathrm{~h}$ to either cisplatin $(0.5 \mu \mathrm{g} / \mathrm{ml})$, carboplatin $(5 \mu \mathrm{g} / \mathrm{ml}$; Calbiochem) or vehicle control $\left(\mathrm{ddH}_{2} \mathrm{O}\right)$ for $24 \mathrm{~h}$ and the experiment was ended at 72 and $240 \mathrm{~h}$ post-exposure. In some cases, there was sufficient material from a biopsy sample to allocate to more than one experimental setup.

\section{Human tissue xenografting}

Testicular tissue pieces from human foetuses $(n=4)$ that were cultured in vitro were used for xenografting at $24 \mathrm{~h}$ post-cisplatin or vehicle exposure. As previously described [16], tissue fragments were grafted subcutaneously into host adult CD1-nude mice using a 13-gauge cancer implant needle (Popper and Sons). For each foetal sample, a total of 4 pieces $\left(\sim 1 \mathrm{~mm}^{3}\right)$ of testicular tissue was inserted under the dorsal skin of the host mouse, with random allocation of two vehicle controls and two $0.5 \mu \mathrm{g} / \mathrm{ml}$ cisplatin-treated pieces along either side of the midline. A total of 4 mice were grafted per foetal sample, and the mice were maintained for 12 weeks post grafting before retrieval of the tissue. Mice were housed in the same location and exposed to $12 \mathrm{~h}$ light/dark cycles and room temperature, $\sim 20-25^{\circ} \mathrm{C}$. Mice were administered $100 \mu \mathrm{l}$ of $20 \mathrm{IU}$ human chorionic gonadotrophin (hCG) (Ovitrelle, Merck Serono) beginning a week after xenografting which was continued three times a week until the end of the experiment. One mouse was culled before the end of the experiment due to poor health and was not included in the analysis. For xenograft retrieval, host mice were culled by inhalation of $\mathrm{CO}_{2}$ and cervical dislocation. Weight of host mouse body and retrieved grafts were recorded.

\section{Tissue processing}

At the end of each experiment, tissue pieces were fixed in Bouin's fluid (Clin-Tech) for $1 \mathrm{~h}$ and transferred to $70 \%$ ethanol. Post fixation, samples were paraffinembedded, $5 \mu \mathrm{m}$ sectioned and assessed by H\&E using standard protocol or used for immunohistochemistry as described below. Only samples that showed healthy tissue morphology (defined tubules, minimal apoptosis and germ cell presence) in pre-culture and vehicle controls were included in the analyses. Two sections from two replicates for each treatment were stained and analysed. 


\section{Immunohistochemistry}

Double colourimetric immunohistochemistry was performed to detect gonocytes and spermatogonia (details of primary antibody in Additional File 1: Table S1).

Sections were dewaxed by incubating in xylene (BDH Prolabo ${ }^{\oplus}$, VWR Chemicals) twice for $5 \mathrm{~min}$ each. Tissue slides were rehydrated in alcohol series (100\% twice, 95\%, $80 \%$ and $70 \%$ ) for $20 \mathrm{~s}$ and thoroughly rinsed in tap water. Heat-induced epitope retrieval of all slides was carried out in a pressure cooker containing $0.01 \mathrm{M}$ citrate buffer. Tissue sections were rinsed in water and blocked with $3 \%$ (v/ v) hydrogen peroxide in methanol for $15 \mathrm{~min}$ on a rocker at room temperature. To minimise cross-reactivity, tissue sections were incubated with blocking agent (consisting of $20 \%$ appropriate animal serum in Tris-buffered saline (TBS, $0.01 \mathrm{M}$ Tris, $0.85 \%$ sodium chloride, $\mathrm{pH} 7.4$ ) and $5 \mathrm{~g}$ of bovine serum albumin (BSA, Sigma-Aldrich, $\mathrm{GmbH}$ )) for $30 \mathrm{~min}$ at room temperature. Primary antibody diluted in blocking agent was added to tissue sections for overnight incubation at $4{ }^{\circ} \mathrm{C}$.

To detect the primary antibody, slides were incubated with peroxidase (ImmPRESS, Vector Laboratories) for $30 \mathrm{~min}$ at room temperature. Each incubation step was followed by two 5 -min washes in TBS. To visualise the first antibody, 3,3-diaminobenzidine (DAB, Vector Laboratories) was added and colour development (usually up to $3 \mathrm{~min}$ ) was monitored microscopically and stopped by washing in deionised water. Prior to the second antibody detection, antigen epitopes were retrieved by placing slides in pre-heated $0.01 \mathrm{M}$ citrate buffer and boiling for $2.5 \mathrm{~min}$ using a microwave. Once cooled, slides were blocked with appropriate normal serum/ TBS/BSA for $30 \mathrm{~min}$ at room temperature, followed by an overnight incubation at $4{ }^{\circ} \mathrm{C}$ with subsequent primary antibody diluted in normal serum/TBS/BSA.

To detect the second antibody, tissue sections were incubated with alkaline phosphatase (ImmPRESS, Vector Laboratories) for $30 \mathrm{~min}$ at room temperature, visualised by adding FastBlue substrate (Vector Laboratories), and the reaction was stopped by rinsing in deionised water. Slides were mounted with PermaFluor aqueous medium (Lab Vision ${ }^{\mathrm{Tm}}$, Thermo Scientific). Images were taken on Axio Scan.Z1 slide scanner (Carl Zeiss Microscopy, $\mathrm{GmbH})$ at $\times 20$ magnification.

In addition, each experiment involved positive (all reagents added) and negative controls (primary antibody replaced with blocking agent) of pre-culture controls from each foetal sample. Slides for different treatments of the same foetal sample were all processed in parallel in a single experiment.

\section{Immunofluorescence}

Dewaxing, rehydration, antigen retrieval and blocking of endogenous peroxidase and appropriate serum blocking were performed as described above for immunohistochemistry. To detect the primary antibody, slides were incubated with peroxidase-conjugated secondary antibody for $30 \mathrm{~min}$ and visualised using Tyramide signal amplification kit (PerkinElmer, Inc.) at 1:50 for $10 \mathrm{~min}$ (both steps at room temperature). Antigen retrieval was performed using microwave treatment prior to adding subsequent primary antibodies. Same detection steps using different fluorophores were performed for each primary antibody. Nuclei were counterstained with Hoechst (Thermo Fisher Scientific) diluted in TBS at 1: 2000. Tissue sections were mounted with Permafluor (Lab Vision ${ }^{\mathrm{TM}}$, Thermo Scientific), and tiled images of the whole tissue section were captured at $\times 20$ magnification using LSM 780 Confocal microscope (Carl Zeiss Microscopy, GmbH). Primary and secondary antibody details used for single and triple immunofluorescent staining are in Additional File 1: Table S1.

\section{Statistics}

Positively stained cells were manually counted and tubular, and tissue areas were measured using Zen 2.3 lite Blue Edition (Carl Zeiss Microscopy, GmbH) software. The interstitial area was obtained by subtracting the tubular area from the tissue area. All tubules per tissue section were included in the analysis. Cell numbers per tubular or tissue area $\left(\mathrm{mm}^{2}\right)$ were calculated and plotted. Percentage in cell number in comparison to control was also calculated. Data were presented as mean +/- SEM. Two-way ANOVA statistical analysis was performed in order to account for inter-individual sample variation using GraphPad Prism 8 software (La Jolla, CA, USA). Statistical significance was set to $p<0.05$.

\section{Single-cell sequencing analysis}

Single-cell RNA sequencing was previously performed on human prepubertal testis ranging from 1 to 11 years of age [7]. The resulting dataset was interrogated to define the cell states and populations present in the testis of a 7-year-old, whilst MAGEA4 (spermatogonia) and UTF1 (SSCs) expression was extracted from the dataset for individuals aged 1, 7 and 11 years. Data were presented as t-SNE and violin plots.

\section{Results}

Cisplatin exposure results in differential germ cell loss in human foetal testis

Human foetal testicular tissues $(n=11,14-22$ GW) were exposed in vitro to cisplatin $(0.5$ and $1.0 \mu \mathrm{g} / \mathrm{ml})$ or vehicle for $24 \mathrm{~h}$, and germ cells per tubular area $\left(\mathrm{mm}^{2}\right)$ were quantified at 24 and $96 \mathrm{~h}$ post-exposure (Fig. 2). Germ cell populations consisted of gonocytes $\left(\mathrm{AP} 2 \gamma^{+}\right)$and (pre)spermatogonia (MAGEA4 $\left.{ }^{+}\right)$ (Fig. 2a-c). At $24 \mathrm{~h}$ post-exposure, there was no 


\section{HOURS}
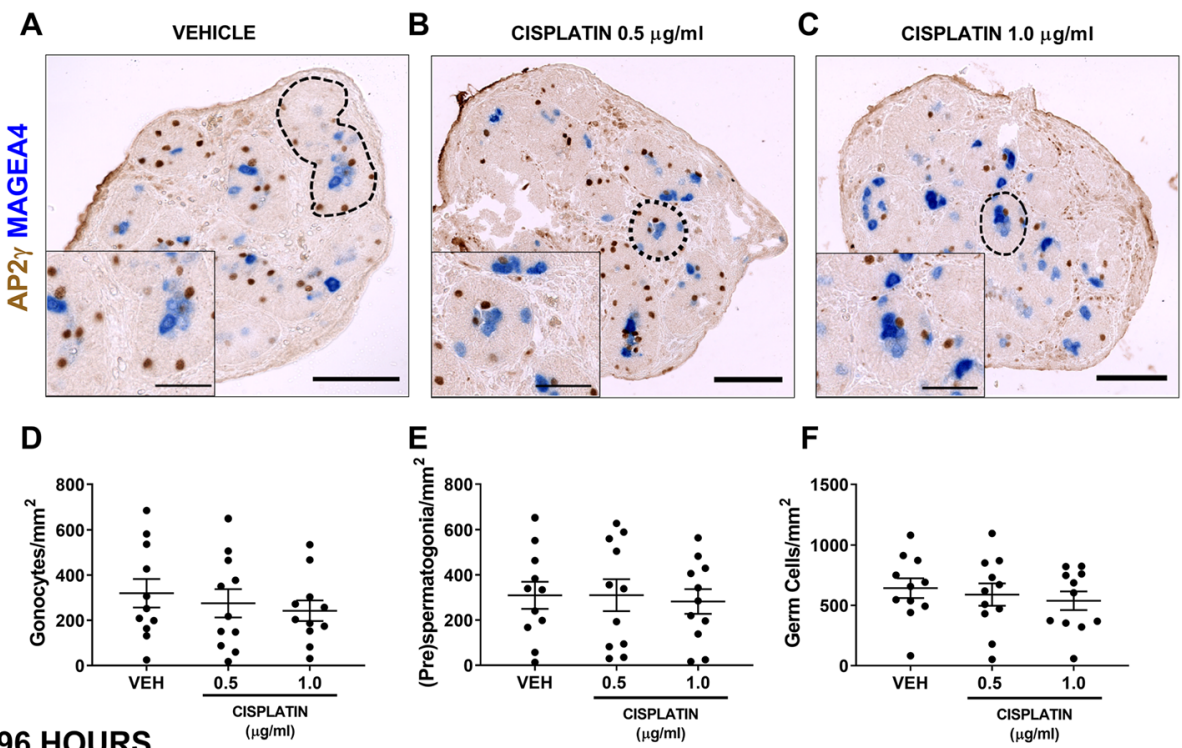

\section{$\mathbf{F}$}

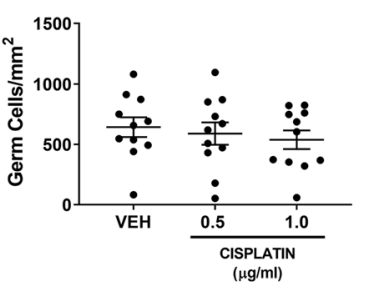

G

H CISPLATIN $0.5 \mu \mathrm{g} / \mathrm{ml}$

I CISPLATIN $1.0 \mu \mathrm{g} / \mathrm{ml}$
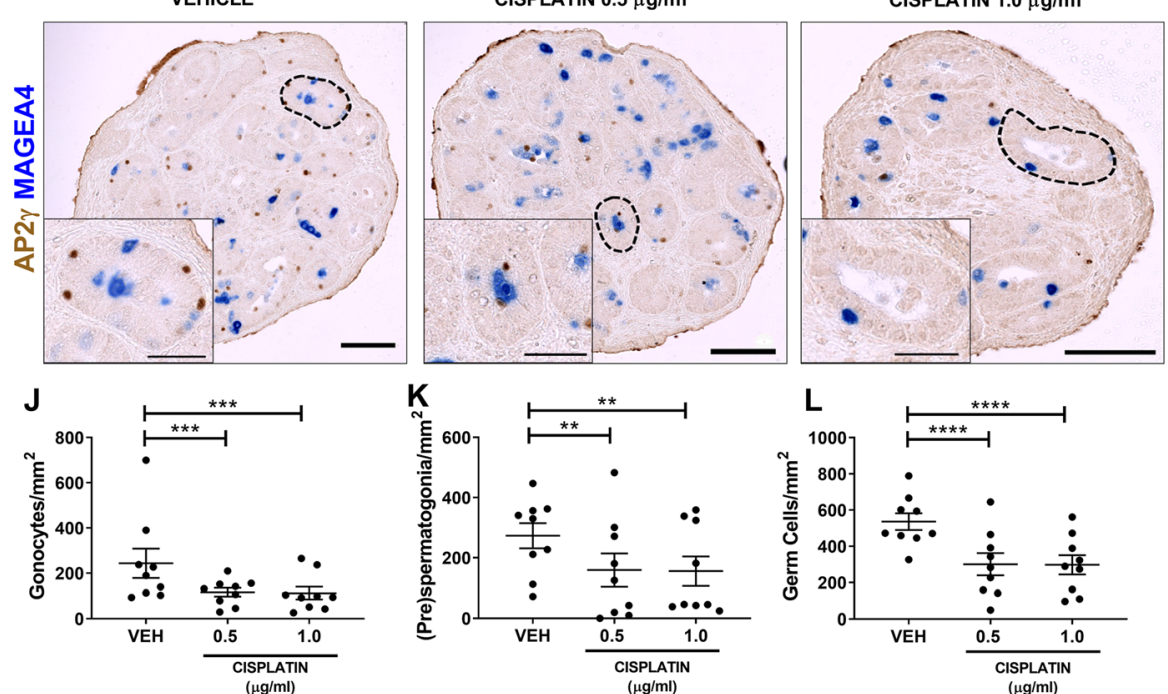

Fig. 2 Acute effects of cisplatin exposure on germ cell populations in the human foetal testis. AP $2 \gamma^{+}$gonocytes (brown) and MAGEA4 ${ }^{+}$ (pre)spermatogonia (blue) protein expression in the human foetal testis $24 \mathrm{~h}(\mathbf{a}-\mathbf{c})$ and $96 \mathrm{~h}(\mathbf{g}-\mathbf{i})$ following exposure to vehicle or cisplatin $(0.5$ and $1.0 \mu \mathrm{g} / \mathrm{ml}$ ). Scale bars represent $100 \mu \mathrm{m}$ (or $50 \mu \mathrm{m}$ for insets). Dotted lines outline seminiferous tubules. Quantification of germ cell counts per tubular area $\left(\mathrm{mm}^{2}\right)$ in the human foetal testicular tissues $24 \mathrm{~h}(\mathbf{d}-\mathbf{f})$ and $96 \mathrm{~h}(\mathbf{j}-\mathbf{I})$ following exposure to vehicle (VEH) or cisplatin $(0.5 \mathrm{and} 1.0 \mathrm{\mu g} /$ $\mathrm{ml})$. Germ cell numbers were unaffected $24 \mathrm{~h}$ post-exposure, whilst a significant reduction in number of gonocytes, (pre)spermatogonia and total germ cells was observed at $96 \mathrm{~h}$ following exposure to $0.5 \mu \mathrm{g} / \mathrm{ml}$ and $1.0 \mu \mathrm{g} / \mathrm{ml}$ cisplatin exposure. Data analysed using two-way ANOVA. ${ }^{* *} p<$ $0.01,{ }^{* * *} p<0.001$ and ${ }^{* * *} p<0.0001$. Values shown are means \pm SEM and each data point represents an individual foetus $(n=9-11)$

significant difference in either germ cell population in cisplatin-exposed compared to vehicle-exposed testicular tissues (Fig. 2d-f). However, at $96 \mathrm{~h}$ postexposure, germ cell loss was evident for cisplatin exposure at both concentrations (Fig. 2g-i). Quantification showed that both germ cell populations (gonocytes and (pre)spermatogonia) were significantly reduced in cisplatin-exposed testicular tissues (Fig. 2j, k) and overall total germ cell number (gonocytes + (pre)spermatogonia) was reduced by $44 \%$ for both $0.5 \mu \mathrm{g} / \mathrm{ml}(301 \mathrm{v} 536, p<0.0001)$ and $1.0 \mu \mathrm{g} / \mathrm{ml}(298 \mathrm{v}$ $536, p<0.0001)$ cisplatin exposures (Fig. 2l). Since the degree of germ cell loss was similar with both concentrations of cisplatin, further experiments were focused on exposure to $0.5 \mu \mathrm{g} / \mathrm{ml}$ cisplatin only.

In order to determine the timing of germ cell loss for gonocytes and (pre)spermatogonia, we investigated the effect of cisplatin exposure at an intermediate 
time-point (72 h post-exposure, $n=8$; Fig. 3a-e). There was a significant reduction in the number of gonocytes in cisplatin-exposed testicular tissues ($21 \%, 380$ v 479, $p<0.01$; Fig. 3c). However, (pre)spermatogonial number was unchanged in cisplatinexposed testicular tissues compared with vehicle control (270 v 281, $p>0.05$; Fig. 3d). Despite the fact that (pre)spermatogonial number was not affected by cisplatin exposure, the loss of gonocytes was sufficient to cause a significant overall reduction in total germ cell number $(-15 \%, 650$ v 763, $p<0.01$; Fig. 3e).

Progression of cisplatin-induced germ cell loss was investigated in testicular tissues at $240 \mathrm{~h}$ post cisplatinexposure $(n=14$; Fig. $3 \mathrm{f}-\mathrm{j})$. The reduction in gonocyte (-41\%, 194 v 327, $p<0.0001$; Fig. 3h), (pre)spermatogonia $(-18 \%$, 324 v 393, $p<0.01$; Fig. 3i) and total germ cell number $(-37 \%, 433$ v 691, $p<0.0001$; Fig. 3j) was maintained over the extended culture period.

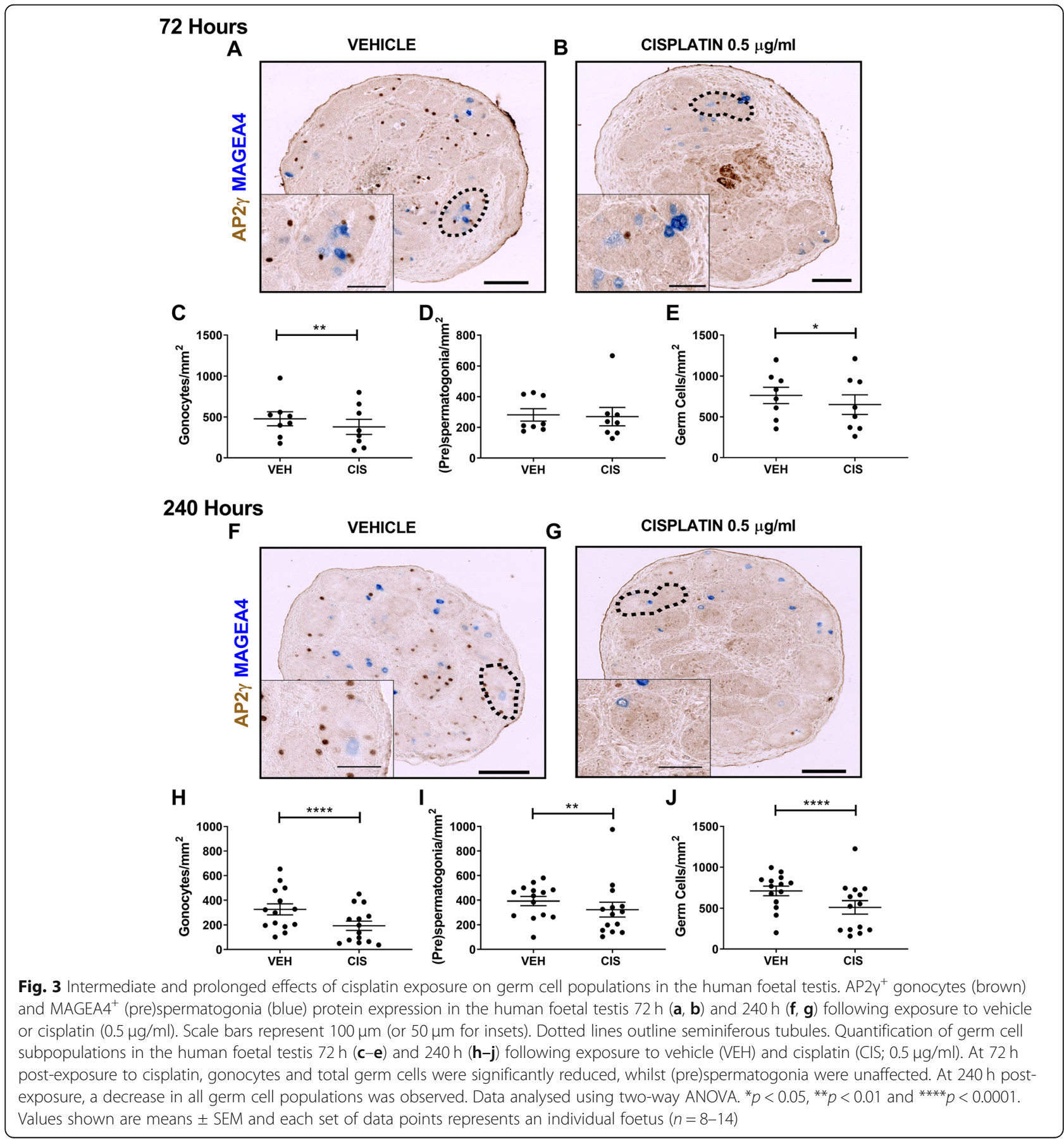


Cisplatin exposure reduces cell proliferation in both germ cell populations in human foetal testis

To investigate further the reason for germ cell loss in cisplatin-exposed testicular tissues, we assessed apoptosis by immunostaining for cleaved caspase 3 (CC3) (Additional File 2: Figure S2). There was no significant difference in total number of apoptotic $\left(\mathrm{CC}^{+}\right)$cells in the seminiferous cords of cisplatin-exposed testicular tissues, compared to vehicle controls at either 24 or $96 \mathrm{~h}$ post-exposure.
Apoptotic cells in the interstitium were also extremely rare in both cisplatin-exposed and vehicle control tissues. Therefore, we assessed proliferation $\left(\mathrm{Ki} 67^{+}\right)$as an explanation for germ cell population loss in cisplatin-exposed testicular tissues at $24 \mathrm{~h}$ post-exposure (Fig. $4 \mathrm{a}, \mathrm{b}$ ). At this time-point, there were no significant differences in proliferation of either germ cell population following cisplatinexposure (Fig. 4c-e). However, at $96 \mathrm{~h}$ post-exposure (Fig. 4f, g), there was a reduction in proliferating germ cells

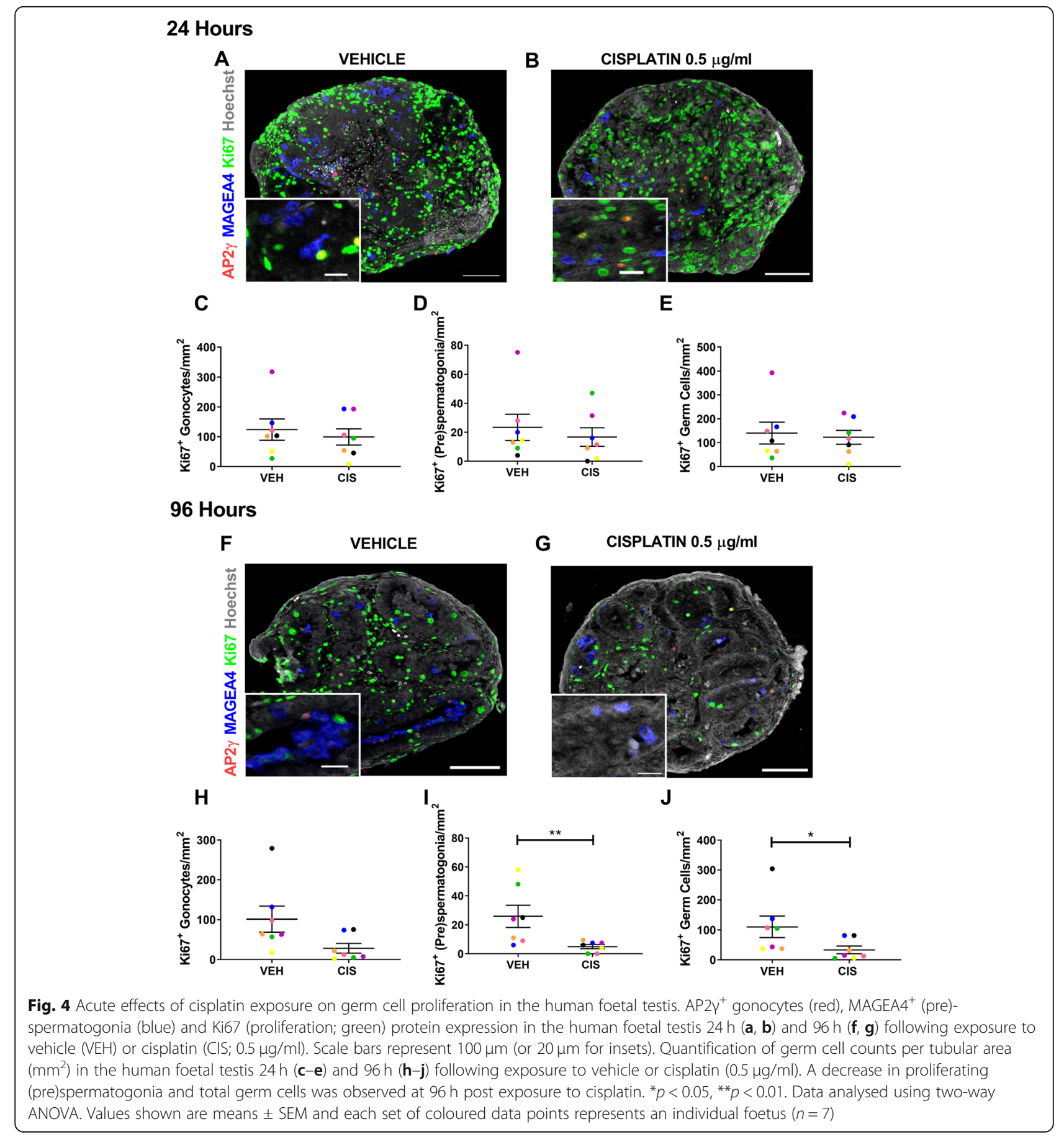


in cisplatin-exposed testicular tissues, compared with vehicle controls (Fig. 4h-j). Proliferating (pre)spermatogonia were significantly reduced $(-81 \%, 5$ v $26, p<0.01$; Fig. $4 \mathrm{i})$ by cisplatin exposure, and whilst there was a similar trend towards reduction in proliferating gonocytes $(-71 \%, 28 \mathrm{v}$ 101, $p=0.06$; Fig. 4e), this did not reach statistical significance. Overall, proliferation was decreased in the total germ cell population $(-70 \%, p<0.05$; Fig. $4 \mathrm{j})$.

These data demonstrate acute and specific loss of germ cells from the seminiferous epithelium of human foetal testicular tissues following cisplatin exposure. Furthermore, there was a differential effect in the timing of germ cell loss, with gonocyte number being reduced at an earlier timepoint (72 h) compared to (pre)spermatogonial number (96 h). This germ cell loss was associated with a reduction in the number of proliferating germ cells in the testis.
Exposure to cisplatin results in long-term germ cell loss in human foetal testis xenografts

To determine whether there is potential for recovery from acute cisplatin-induced loss of germ cells, given the ongoing albeit reduced rate of germ cell proliferation, human foetal $(n=4)$ testicular tissue pieces that had been exposed to cisplatin in vitro were xenografted subcutaneously into immunocompromised host mice for 12 weeks (Fig. 4). Graft retrieval rates were similar for mice xenografted with cisplatin-exposed testicular tissues compared with vehicle controls (90 v 77\%, $p>0.05$ ). Seminiferous cord structure was maintained and both germ cell populations were identified in vehicle (Fig. 5a) and cisplatin-exposed (Fig. 5b) xenografts. However, mean retrieved xenograft weights $(\mathrm{mg})$ were significantly reduced in the cisplatin-exposed group compared with vehicle controls $(-50 \%, 0.50 \mathrm{v} 1.02, p<$
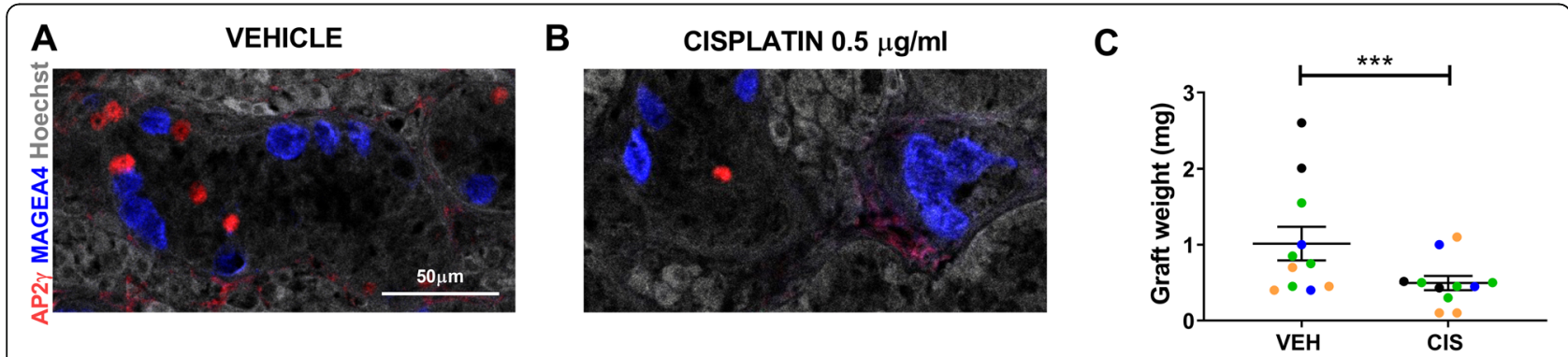

D
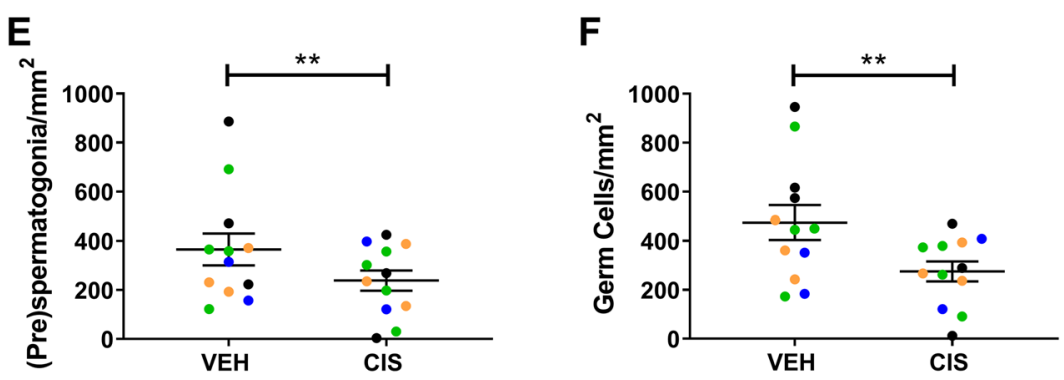

G

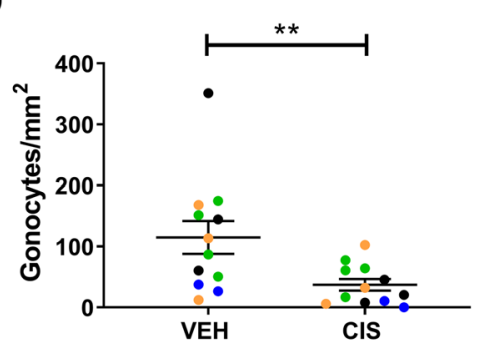

E

I
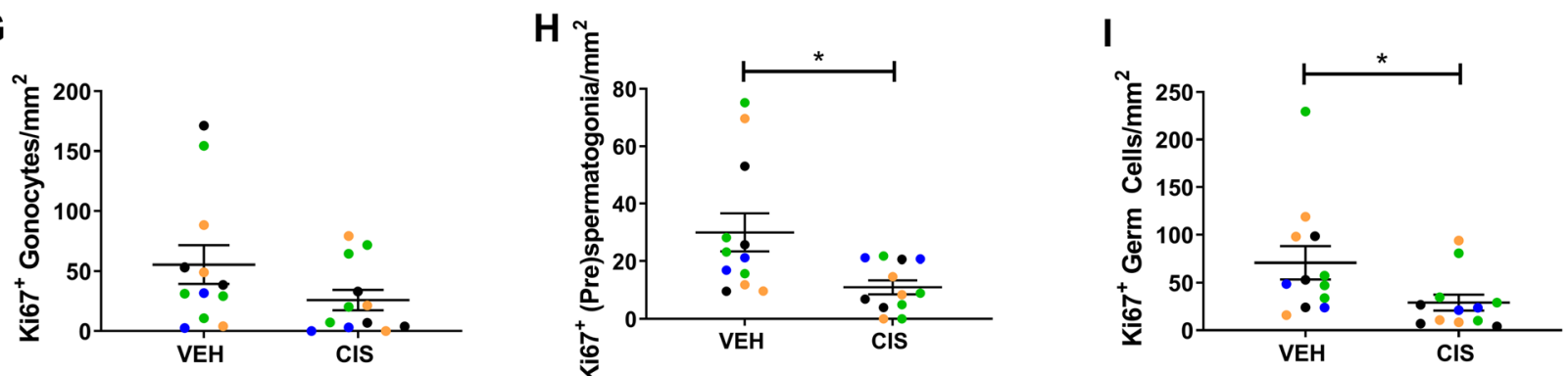

Fig. 5 Long-term effects of cisplatin exposure on human foetal testis xenografts. Immunohistochemistry for AP2 $\gamma^{+}$gonocytes (red) and MAGEA4 ${ }^{+}$ (pre)-spermatogonia (blue) in human foetal testis tissues exposed to vehicle (VEH; a) or cisplatin (CIS; b) for $24 \mathrm{~h}$ prior to xenografting (12 weeks). Total graft weight (c) was significantly reduced following cisplatin-exposure. Quantification of cell number (d-fi) and proliferation ( $\mathbf{g}-\mathbf{i})$ of germ cell populations per tubular area $\left(\mathrm{mm}^{2}\right)$ in xenografts. A significant decrease in all germ cells populations was observed in cisplatin-exposed tissues. Proliferating (pre)spermatogonia and total germ cells were also significantly reduced in cisplatin-exposed tissues after long-term xenografting. Data analysed using two-way ANOVA. ${ }^{*} p<0.05,{ }^{* *} p<0.01$ and ${ }^{* * *} p<0.001$. Values shown are means \pm SEM and each set of coloured data points represents an individual foetus $(n=4)$ 
0.001; Fig. 5c). Assessment of xenografts at 12 weeks postgrafting revealed a significant reduction in gonocyte $(-68 \%$, 37 v 115, $p<0.01$; Fig. 5d), (pre)spermatogonial (-35\%, 238 v 366, $p<0.01$; Fig. 5e) and total germ cell $(-42 \%, 276 \mathrm{v}$ $475, p<0.01$; Fig. 5f) numbers in cisplatin-exposed xenografts compared with vehicle control xenografts. The reduction in graft weight and in total germ cell number in the cisplatin-exposed group could result from either persistent cell loss or a reduction in cell proliferation. Therefore, we quantified proliferation in the germ cell sub-populations (Fig. $5 \mathrm{~g}-\mathrm{i}$ ). There was a significant reduction in proliferation of (pre)spermatogonia $(-63 \%, 11$ v $30, p<0.05$; Fig. $5 \mathrm{~h})$ and total germ cells $(-59 \%, 27$ v 65, $p<0.05$; Fig. 5i); however, the similar degree of reduction in gonocytes was not statistically significant $(-53 \%, 26 \mathrm{v} 55, p>0.05$; Fig. $5 \mathrm{~g})$.

Taken together, these data indicate that cisplatininduced (pre)spermatogonial loss persists in the immature human testis for several months post-exposure and that germ cell proliferation is not sufficiently increased to compensate for this loss.

\section{Cisplatin-exposure leads to loss of spermatogonial stem cells in the human prepubertal testis}

Spermatogonia in the prepubertal human testis have been shown to express MAGEA4, with a sub-population of spermatogonia co-expressing UTF1 believed to represent spermatogonial stem cells (SSCs) [7]. Given that future fertility is dependent on the survival of the SSC population, we interrogated our recent single-cell transcriptomics data from prepubertal human testicular tissues for MAGEA4 and UTF1 [7]. In tissues obtained from a 7-year-old boy, germ cells were represented by a distinct cluster separate from somatic cell populations (Fig. 6a). MAGEA4 showed relatively stable expression in germ cells of boys aged 1, 7 and 11 years, whilst relative expression of UTF1 was reduced with increasing age (Fig. 6b), probably due to progression towards spermatogonial differentiation [7]. To determine whether cisplatin-exposure in prepuberty results in a similar germ cell (MAGEA4 $\left.{ }^{+}\right)$loss to that described for the human foetal testis and if this included the spermatogonial stem cell $\left(\mathrm{MAGEA} 4^{+} / \mathrm{UTF} 1^{+}\right.$) population, we performed in vitro culture of prepubertal testicular tissue obtained from boys prior to chemotherapy exposure $(n=3-5,1-$ 12 years). Tissues were exposed to cisplatin $(0.5 \mu \mathrm{g} / \mathrm{ml})$ for $24 \mathrm{~h}$, with analysis at $24(n=5$, aged $1,1,8,11$ and 12 years) and $96 \mathrm{~h}(n=3$, aged 1,1 and 12 years) postexposure (Fig. 6c-h). Cisplatin-exposure did not result in a significant change in the total number of spermatogonia at $24 \mathrm{~h}$ post-exposure ( $536 \mathrm{v} 496, p>0.05$; Fig. $6 \mathrm{~d}$ ). Overall, SSC number was reduced in prepubertal human testicular exposed to cisplatin at $24 \mathrm{~h}$ post-exposure, compared to vehicle-exposed controls, although this was not statistically significant ( $16 \mathrm{v} 75, p>0.05$; Fig. 6e). As there was sufficient testicular tissue available from three of the patients (aged 1, 1 and 12 years), we also investigated the effects of cisplatin treatment at $96 \mathrm{~h}$ postexposure. Quantification showed that there was a significant reduction in total spermatogonial number $(-30 \%$, $310 \mathrm{v} 446, p<0.05$; Fig. $6 \mathrm{G})$ and a reduction in SSC number $(-52 \%, 6.5$ v 13.5, $p<0.05$; Fig. $6 \mathrm{H})$, compared to vehicle-exposed controls. Importantly, there were no SSCs remaining in the cisplatin-exposed group for 2 out of 3 patients (aged 1 and 12 years) (Fig. 6h).

In summary, these results demonstrate cisplatininduced germ cell loss in prepubertal human testicular tissues, including a reduction or loss of the SSC population. The degree and timing of spermatogonial cell loss was similar to that seen in human foetal testicular tissues after cisplatin exposure. This provides further validation for the use of the human foetal testis as a relevant model system for studying impacts of exposures during prepuberty, whilst also demonstrating consistent germ cell effects at different key stages of human testicular development.

\section{Carboplatin induces similar effects to cisplatin on germ cell populations in the human foetal testis}

Carboplatin is used in clinical practice as an alternative to cisplatin because of its reported lower risk of side effects. Therefore, we aimed to determine whether carboplatin exposure resulted in a reduction in gonadotoxicity compared with cisplatin, at equivalent human-relevant concentrations. Human foetal testicular tissues $(n=6)$ were exposed in vitro to cisplatin $(0.5 \mu \mathrm{g} / \mathrm{ml})$, carboplatin $(5 \mu \mathrm{g} / \mathrm{ml})$ or vehicle for $24 \mathrm{~h}$ : carboplatin was administered at 10 times the concentration to cisplatin in line with relative therapeutic doses used in patients. Germ cells were quantified at 72 and $240 \mathrm{~h}$ post-exposure (Fig. 7). At $72 \mathrm{~h}$ post-exposure, there was a significant reduction in gonocytes in cisplatin-exposed compared to vehicle-exposed tissues $(-28 \%, 193 \mathrm{v} 267, p<0.01)$, whilst carboplatin did not result in a significant change in gonocyte number (Fig. 7a). (Pre)spermatogonia and total germ cell number were unaffected after $72 \mathrm{~h}$ for both platinum-based agents (Fig. 7b, c). However, at $240 \mathrm{~h}$ post-exposure, gonocytes were significantly reduced to a similar extent following exposure to cisplatin $(-67 \%, 76 \mathrm{v} 228, p<0.0001)$ or carboplatin $(-58 \%, 96 \mathrm{v}$ $228, p<0.0001)$, compared with vehicle-exposed controls (Fig. 7d). (Pre)spermatogonial numbers were similar between cisplatin- and carboplatin-exposed testicular tissues after $240 \mathrm{~h}$ and were not significantly different to vehicle controls (Fig. 7e). However, total germ cell number was significantly reduced by a similar amount in both cisplatin- $(-30 \%, 492 \mathrm{v} 704, p<0.01)$ and carboplatin-exposed tissues $(-28 \%, 509$ v 704, $p<0.05)$ compared to vehicle control (Fig. 7f). 

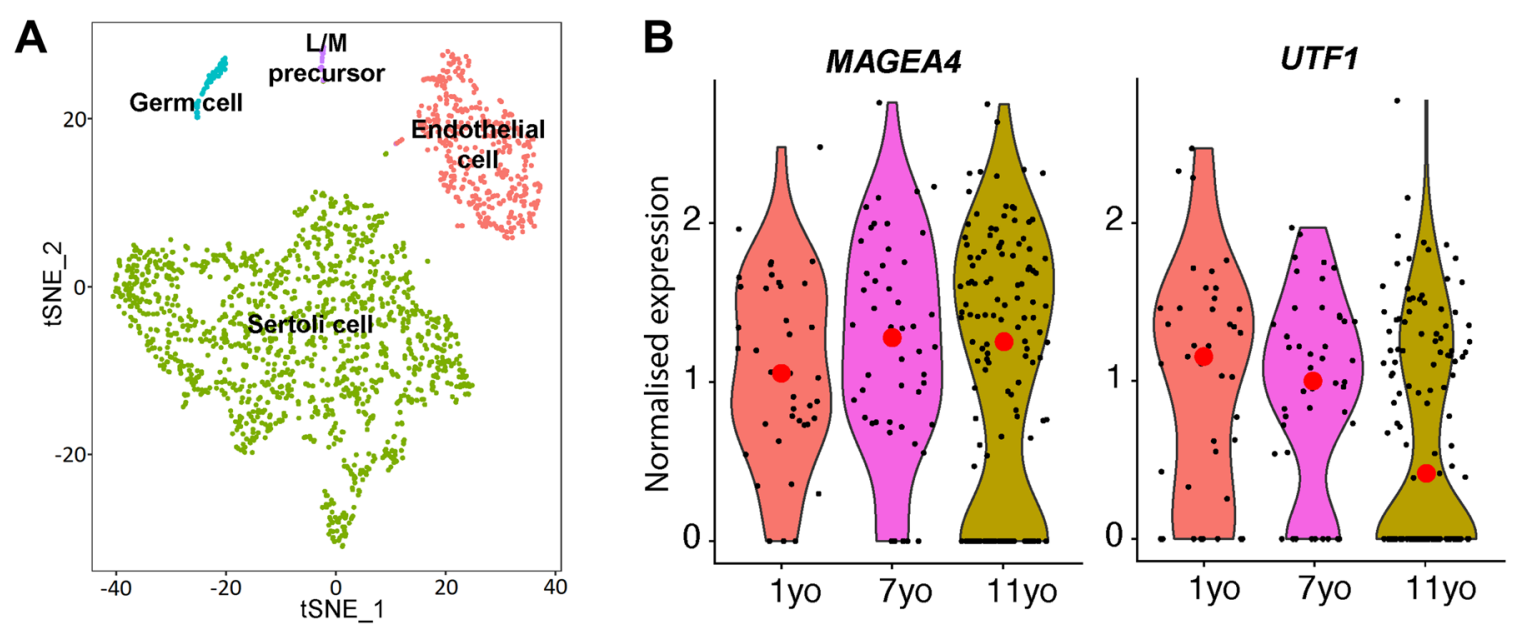

\section{Hours}
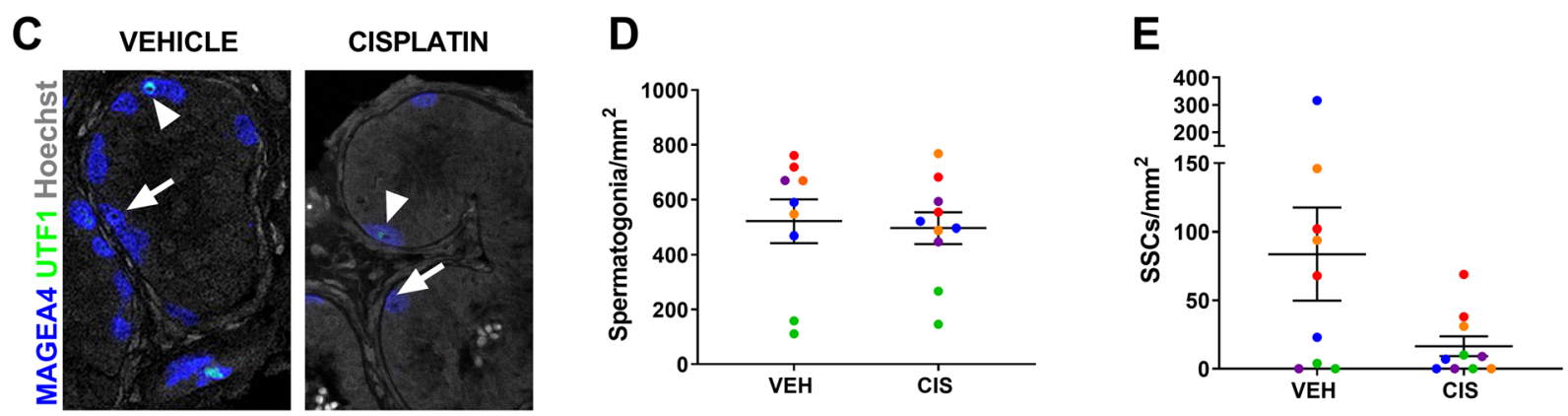

\section{Hours}

$\mathbf{F}$

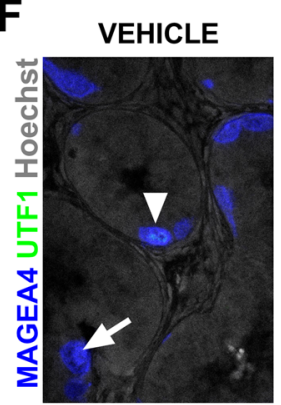

CISPLATIN

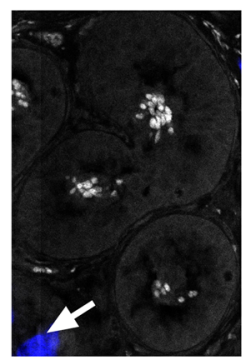

G

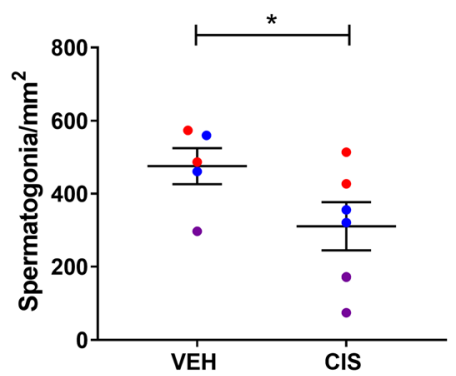

H

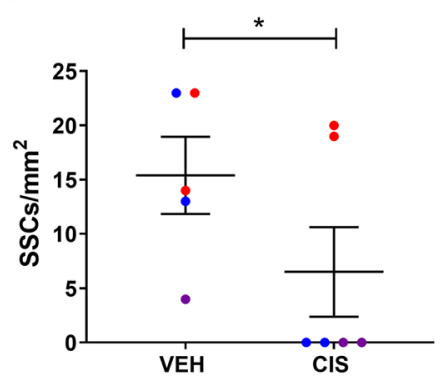

Fig. 6 Effects of cisplatin exposure on human prepubertal testis. a t-SNE plot of cell populations obtained during single-cell sequencing of testicular tissue of a 7-year-old male. b Violin plots for normalised expression of (pre)spermatogonium (MAGEA4) and SSC (UTF1) populations in testicular tissues from 1-, 7- and 11-year-old (yo) males. Red dots represent mean expression. Effect of cisplatin (CIS, 0.5 Mg/ml) exposure on MAGE $\mathrm{A} 4^{+}$spermatogonia (blue) and UTF1 ${ }^{+}$(green) SSCs in the human prepubertal testis $24 \mathrm{~h}(\mathbf{c}-\mathbf{e})$ and $96 \mathrm{~h}(\mathbf{f}-\mathbf{h})$ after exposure compared to vehicle (VEH) control. A significant decrease in spermatogonia and SSCs was observed at $96 \mathrm{~h}$ post-cisplatin exposure. Data analysed using two-way ANOVA. ${ }^{*} p<0.05$. Values shown are means \pm SEM and each set of coloured data points (blue and red -1 year, orange -8 years, green -11 years, purple-12 years) represents an individual patient $(n=3-5)$. c, f Arrows - spermatogonium (MAGEA4 ${ }^{+}$), arrowheads-SSC

subpopulation (MAGEA4 ${ }^{+} / \mathrm{UTF}^{+}$)

Taken together, these results demonstrate that clinically equivalent exposure to carboplatin results in similar effects on the germ cell population of the immature human testicular tissues to those of cisplatin.

\section{Discussion}

The present study, using validated experimental models, demonstrates that exposure to platinum-based chemotherapy agents results in acute loss of germ cells in the immature human testis and that this germ cell loss does 


\section{Hours}

A

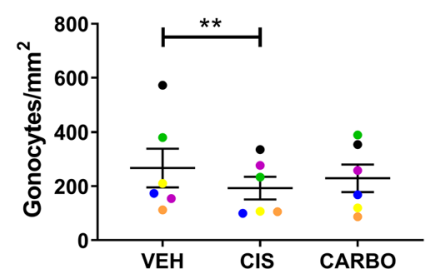

240 Hours

D

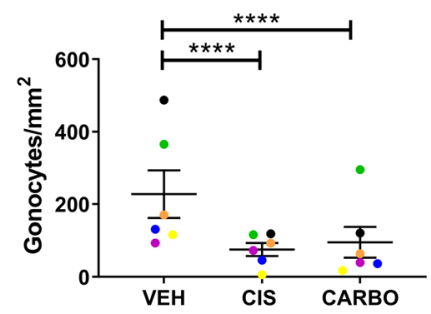

B

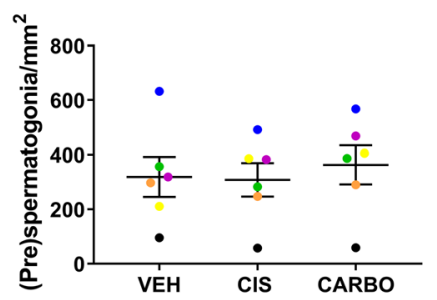

C

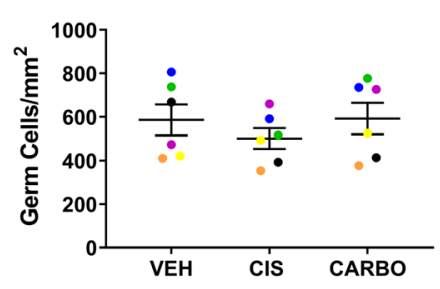

E

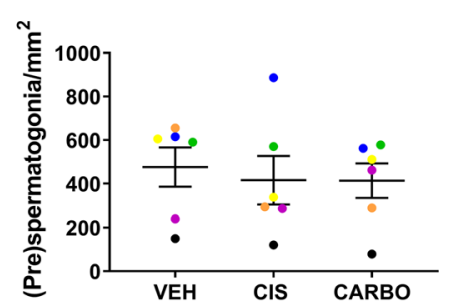

$\mathbf{F}$

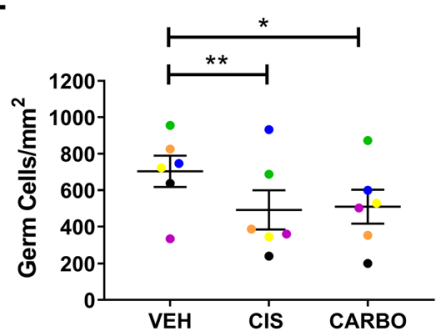

Fig. 7 Comparison of cisplatin and carboplatin exposure on germ cell populations of the human foetal testis. Quantification of germ cell subpopulations in the human foetal testis $72 \mathrm{~h}(\mathbf{a}-\mathbf{c})$ and $240 \mathrm{~h}(\mathbf{d}-\mathbf{f})$ following exposure to vehicle (VEH), cisplatin (CIS; $0.5 \mu \mathrm{g} / \mathrm{ml})$ or carboplatin $(\mathrm{CARBO} ; 5 \mathrm{\mu g} / \mathrm{ml})$. At $72 \mathrm{~h}$ post-exposure, gonocytes were significantly reduced for cisplatin only. At $240 \mathrm{~h}$ post exposure, a decrease in gonocytes and total germ cells was observed following exposure to either cisplatin or carboplatin. Data analysed using two-way ANOVA. ${ }^{*} p<0.05$, ${ }^{* *} p<0.01$ and ${ }^{* * *} p<0.0001$. Values shown are means \pm SEM and each set of data point represents an individual foetus $(n=6)$

not recover several months after exposure. The results also indicate a differential decline in germ cell populations, involving an initial loss of gonocytes followed by a reduction of spermatogonia. Importantly, the effects of carboplatin were similar to those of cisplatin, based on human-relevant drug concentrations.

Cisplatin exposure resulted in a significant reduction in total germ cells in both foetal and prepubertal human testicular tissues in culture. This is in keeping with a previous in vitro study in rodents, which demonstrated a reduction in germ cell number in prepubertal mouse testicular tissues exposed to cisplatin [17]. In that study, there was a $>95 \%$ reduction in germ cell number $72 \mathrm{~h}$ after cisplatin exposure, whereas the reduction in germ cells in the present study was $\sim 70-80 \%$ at $96 \mathrm{~h}$ postexposure.

A key finding from the present study was the reduction in the SSC pool in prepubertal human testicular tissues following exposure to platinum-based chemotherapy. SSCs represent the key population required for repopulation and restoration of spermatogenesis in the adult testis following gonadotoxic therapy in primates [18]. Implementation of single-cell transcriptomics has allowed a detailed characterisation of spermatogonial populations present within the adult human testis $[19,20]$ and several SSC 'states' each with a unique transcriptional profile have been described [19]. This approach has also been applied to the human prepubertal testis, indicating the existence of similar SSC signatures, including the expression of UTF1 as a key feature of the SSC pool [7]. The present study demonstrates that exposure to cisplatin in vitro results in a $52 \%$ reduction in SSCs $\left(\right.$ MAGEA4 $^{+} / \mathrm{UTF}^{+}{ }^{+}$) in the prepubertal human testicular tissues. Importantly, this overall reduction in SSCs includes 2 out of 3 patients (aged 1 and 12 years) in whom no SSCs were identified in the tissue $96 \mathrm{~h}$ after exposure. This suggests that fertility may be permanently impaired in some individuals receiving therapeutic doses of cisplatin, consistent with the association of cisplatin exposure with infertility in male childhood cancer survivors [4]. Further studies involving a larger number of patient samples are required to reduce the impact of individual variability and determine whether SSC loss following platinum-based chemotherapy is dependent on age or pubertal status. The present findings are of potential importance for counselling patients on future fertility and for fertility preservation options. Current strategies to preserve fertility in prepubertal boys involve cryopreservation of testicular material $[8,21]$. However, the future success of this process to restore fertility later in life is dependent on the preservation of germ cells with stem cell capability of cryopreserved tissues [22]. It is 
conceivable that some of the surviving (MAGEA4 ${ }^{+}$ $/ \mathrm{UTF}^{-}{ }^{-}$) germ cells in these patients may retain, or acquire, SSC capabilities following gonadotoxic therapy, as has been demonstrated in mouse models of testicular regeneration and repair following exposure to busulphan, a chemotherapeutic belonging to the highly gonadotoxic group of alkylating agents [23].

The impacts of exposure to chemotherapy during childhood on subsequent reproductive function have been investigated in clinical cohorts of childhood cancer survivors $[3-5,24]$. These studies demonstrate that exposure to alkylating agents is associated with infertility in males [5]. For cisplatin, the data is less consistent. Exposure to platinum-based chemotherapy was not associated with a reduction in partner pregnancy rates in one cohort of childhood cancer survivors [25], whilst two other studies involving the Childhood Cancer Survivor Study reported a significant reduction in partner pregnancy rates in cancer survivors treated with platinum agents compared to their siblings $[4,5]$. Clinical studies involving childhood cancer survivors are limited in their ability to determine the effects of individual agents as they usually involve individuals who have received a variety of treatments, including combined therapies which result in series of small numbers of patients receiving like-for-like treatments. Therefore, studies involving human-relevant experimental systems can be useful to determine the specific effects of an individual agent on testicular germ cells.

The search for effective cancer therapies with reduced side-effects has prompted the development of new generations of drugs with lower cytotoxicity. Therefore, we compared the relative gonadotoxicity of cisplatin with carboplatin and showed that there were minimal differences in the impact on germ cell numbers between these two platinum-based therapies. Exposure to either agent resulted in a significant reduction in germ cell number in human foetal testicular tissues with a similar degree of germ cell loss in cisplatin- $(-34 \%)$ compared to carboplatin-exposed $(-26 \%)$ testicular tissues at $240 \mathrm{~h}$ post-exposure. Although the reduction in (pre)spermatogonial numbers in the cisplatin-exposed group did not reach statistical significance, there was a similar magnitude of reduction to the initial cisplatin-exposure studies and this is likely to be explained by the smaller number of foetal testicular samples used in the cisplatincarboplatin studies. Importantly, the present work used exposures that reflect differences in the doses given to patients in clinical practice: carboplatin is given at $\sim 10$ times the dose of cisplatin and therefore the concentrations used in our in vitro treatments reflected this difference. The finding of no difference in relative gonadotoxicity between the two agents is consistent with a recent study comparing in vitro exposure in prepubertal murine testis [26]. This study demonstrated a significant reduction in spermatogonia in both cisplatin- and carboplatin-exposed testis when compared to vehicle-exposed controls with an almost identical proportion of germ cell loss for both drugs [26]. Whilst no advantage of using carboplatin versus cisplatin is demonstrated in relation to gonadotoxicity, the fact that there is no worsening of testicular effects coupled with reported advantages of carboplatin for reducing toxicities in other organs (e.g. ototoxicity) may still support the preferential use of carboplatin. Comparably, replacement of the alkylating agent procarbazine with an alternative (dacarbazine) from the same class is associated with an increased recovery of spermatogenesis without affecting overall patient survival [27]. Overall, these results demonstrate the importance of establishing the relative toxicity on each tissue of potential replacements for current therapies, especially when the replacement is in the same class as the existing agent. Because of the limited availability of human material for research, the analysis had to be performed across broad age groups, ranging from 'second trimester' and 'prepuberty'. Hence, a larger study distinguishing early and late foetal and specific prepubertal periods, e.g. 'mini-puberty' in early postnatal life, may provide further insight into gonadotoxic impacts on the testis at specific stages during development.

This study demonstrates the utility of these novel experimental approaches for assessing the acute and longterm effects of chemotherapy exposures on the human prepubertal testicular tissues. In addition, the experimental models may also be used to study the combination of treatments and repeated exposures to mimic regimens used in clinical practice. This would provide direct experimental evidence to complement the findings from clinical studies involving male childhood cancer survivors [5]. Cancer treatments are rapidly evolving to include novel agents including immunotherapy involving monoclonal antibodies and manipulation of specific cellsignalling pathways. For many of these agents, there is no information on long-term reproductive effects. The presently used experimental test systems provide a human-relevant model that can be used to investigate the gonadotoxicity of these emerging cancer therapies.

The results of this study in relation to the sensitivity of the gonocyte population are important and have implications for chemotherapy treatment given to pregnant women. It is recognised that many chemotherapeutics can induce foetal loss due to global toxicity to the mother; however, when foetal loss is not expected, there may still be effects on gonadal function and germ cell survival of the developing foetal testis. During the first trimester of pregnancy, the germ cell population in the foetal gonad consists primarily of gonocytes [16]. During 
foetal life, there is a gradual transition of the entire germ cell population from gonocyte to (pre)spermatogonia $[16,28]$. In the present study, the acute reduction of gonocytes resulting from in vitro exposure to platinumbased chemotherapy agents was associated with a subsequent reduction in (pre)spermatogonia in the human foetal testis. This indicates that the establishment of the spermatogonial population in the foetus may be sensitive to the chemotherapy regimen given to the mother during pregnancy. This is further supported by the finding that the reduction in (pre)spermatogonial number is maintained in xenografted testicular tissues several months after exposure. We have previously shown that human foetal testis xenografts exhibit good preservation of testicular structure, seminiferous cord appearance and histology compared with ungrafted materials and that development from gonocytes to spermatogonia continues during the graft period, similar to age-matched ungrafted control testis [16]. Hence, the xenograft model represents a suitable system to determine the effects of exposure on germ cells in the human foetal testis.

Few studies have investigated the effects of cisplatin exposure in pregnancy. Cisplatin administered to pregnant women for cervical cancer during the second trimester crosses the placenta resulting in concentrations ranging from 23 to $65 \%$ (cord blood) and 11-42\% (amniotic fluid), compared with those in the maternal circulation [29]. In baboons, administration of carboplatin has been shown to result in foetal serum levels which were $\sim 50 \%$ of those in the maternal serum and significant malformations were noted in $4 \%$ of the exposed foetuses [30]. In rodents, cisplatin accumulated in foetal tissue approximately a week post-administration [31]. Placental transfer occurs through diffusion, although platinum agents also commonly utilise active transport mediated via transporters $\mathrm{p}$-glycoprotein, multi-resistance protein (MRP)-1 and 2 [32], copper influx transporters, ATP7A and ATP7B [33].

Foetal life is a critical period for programming subsequent testicular development and reproductive function [34]. Exposure to a variety of environmental agents and pharmaceuticals during foetal life has previously been shown to result in germ cell loss in rodents and humans [35]. Recent studies have demonstrated that exposure to human-relevant concentrations of acetaminophen (paracetamol) results in a reduction of gonocytes and total germ cell number (including (pre)spermatogonia) in human foetal testicular tissues including acute effects of in vitro exposure and in long-term xenografts [13]. The gonocyte population was predominantly affected in the present study as previously demonstrated for exposure to phthalates [36]. The mechanism for the acute germ cell loss following cisplatin exposure is likely to involve direct damage to the germ cells. We investigated the potential mechanism for cisplatin-induced reduction in germ cell numbers. As previously reported, there is an increase in apoptosis (expressed as percentage of tubules stained with cleaved caspase 3) $8 \mathrm{~h}$ prior to the decrease in germ cell number in cisplatin-treated prepubertal mouse testicular tissues [17]. In contrast, the present study suggests that there is no apparent difference in apoptotic cell number at any time point studied. However, activation of cleaved caspase 3 pathway could occur between 24 and $72 \mathrm{~h}$ post cisplatin exposure, before the reduction in germ cell number becomes apparent. Interestingly, studies involving acetaminophen- or phthalate-exposure have shown that testicular effects may also involve the associated reduction in testosterone during foetal life $[13,14,37]$. The impact of platinumbased agents on somatic (including Leydig) cell function in foetal and early postnatal testicular tissues requires further investigation.

Early postnatal life is also another crucial period for germ cell development and testicular growth [38]. The hypothalamo-pituitary-gonadal axis is active and the completion of gonocyte differentiation into spermatogonia occurs during this period [38]. As a result, gonocyte loss following platinum exposure during infancy may impact on the establishment of the normal pool of SSCs, and fertility in adulthood. This is of particular importance for malignancies (e.g. neuroblastoma) that can arise shortly after birth or during infancy.

\section{Conclusion}

In conclusion, we show that exposure to human-relevant concentrations of platinum-based chemotherapy results in a reduction in germ cell number, including spermatogonial stem cells, in the immature human testis. We observed a similar germ cell loss for cisplatin and carboplatin, suggesting that carboplatin may not have reduced gonadotoxicity compared to cisplatin. These experimental approaches using human tissues can be broadly applied to determining the relative gonadotoxicity of current and novel cancer therapies, which is important for counselling, modification of treatment regimens and developing strategies to preserve fertility in children with cancer.

\section{Supplementary Information}

The online version contains supplementary material available at https://doi. org/10.1186/s12916-020-01844-y.

Additional file 1 : Table S1. Antibodies and dilutions used for immunohistochemistry (IHC) and immunofluorescent (IF) staining.

Additional file $\mathbf{2}$ : Figure S1. Effect of cisplatin exposure on apoptosis in human fetal testis. Cleaved Caspase 3 (CC3) protein expression in the human fetal testis $24 \mathrm{~h}$ following exposure to vehicle $(\mathrm{VEH}$; A) or cisplatin (CIS, $0.5 \mu \mathrm{g} / \mathrm{ml}$; B). Scale bars represent $100 \mu \mathrm{m}$ (or $50 \mu \mathrm{m}$ for insets), arrowheads indicate positively stained cells: (A) cell in the seminiferous 
tubule, (B) cell in the interstitium. There was no significant change in the number of apoptotic cells within tubules at $24 \mathrm{~h}(\mathrm{C})$ and $96 \mathrm{~h}(\mathrm{D})$, and no significant change in the number of apoptotic cells in the interstitium at $24 \mathrm{~h}(\mathrm{E})$ and $96 \mathrm{~h}$ (F) post-exposure to cisplatin. Data analysed using twoway ANOVA. Values shown are means \pm SEM and each set of coloured data points represents an individual fetus $(n=5)$.

\section{Acknowledgements}

We gratefully acknowledge the work of Anne Saunderson, Rosemary Bayne and the staff of the Bruntsfield Suite of the Royal Infirmary of Edinburgh in provision of tissue for these studies and the Human Developmental Biology Resource (www.hdbr.org) for providing some of the foetal material (Joint MRC/Wellcome Trust; Grant No: 099175/Z/12/Z). We also thank Jill Davies and the Oxford Cell \& Tissue Biobank. We also acknowledge William Mungall for assistance with the animal work, specifically grafting the tissue and monitoring the animals post-surgery. We thank Merrill McHoney and Mark Brougham for assistance with clinical/surgical aspects relating to prepubertal patients and Richard Sharpe for his helpful comments on the manuscript.

\section{Authors' contributions}

Conceived and designed the experiments: RTM, MT, GM. Performed the experiments: MT, GM, FL. Analysed the data: RTM, MT, GM, HW, JBS, KJ, AJ, FL, NS, AG. Contributed reagents/materials/analysis tools: SL, JBS, EO, KJ, HW, JG, BC, CA. Wrote the paper: RTM, MT, GM. NS and RTM jointly supervised PhD student MT. All authors have read and approved the manuscript.

\section{Funding}

RTM was supported by a Wellcome Trust Intermediate Clinical Fellowship (Grant No. 098522) and a UK Research and Innovation (UKRI) Future Leaders Fellowship (MR/S017151/1). JBS was supported by the Swedish Childhood Cancer Foundation (TJ2020-0026) and the Birgitta and Carl-Axel Rydbeck's Research Grant for Pediatric Research (2020-00348). A.G. is supported by Wellcome (Investigator Award 21947) and by the National Institute for Health Research (NIHR) Oxford Biomedical Research Centre (BRC). Experimental work was supported by UKRI (MR/S017151/1), Wellcome (Grant No. 098522) and Children with Cancer UK (15-198). This work was undertaken in the MRC Centre for Reproductive Health funded by the Grant MR/N022556/1.

\section{Availability of data and materials}

The data sets used and/or analysed during the current study are available from the corresponding author on reasonable request. Single-cell sequencing data is available online at:

https://humantestisatlas.shinyapps.io/humantestisatlas1/

\section{Ethics approval and consent to participate}

Ethical approval for use of human foetal tissues for research was obtained from the South East Scotland Research Ethics Committee (LREC08/S1101/1), NRES committee North East - Newcastle and North Tyneside 1 (08/H0906/ $21+5)$ and NRES Committee London - Fulham (18/10/0822), and written informed consent was given by the women. Ethical approval for collection and use of human prepubertal testis tissues in research was obtained from the South East Scotland Research Ethics Committee (13/SS0145) and Oxford University Hospitals NHS Foundation Trust (2016/0140). Written informed consent was obtained from patients' parents/guardians and patients, where appropriate.

For studies involving animals, ethical approval was given by the Animal Welfare and Ethical Review Board (AWERB) at the University of Edinburgh, and all procedures carried out were in accordance with UK Home Office guidelines and the Animal (Scientific procedures) Act 1986.

\section{Consent for publication}

Not applicable.

\section{Competing interests}

The authors declare that they have no competing interests.

\section{Author details}

'MRC Centre for Reproductive Health, The Queen's Medical Research Institute, The University of Edinburgh, 47 Little France Crescent, Edinburgh EH16 4TJ, Scotland, UK. 'KK Women's and Children's Hospital, Bukit Timah Rd,
100, Singapore 229899, Singapore. ${ }^{3}$ Edinburgh Royal Hospital for Sick Children, 9 Sciennes Road, Edinburgh EH9 1LF, Scotland, UK. ${ }^{4}$ NORDFERTIL Research Lab Stockholm, Childhood Cancer Research Unit, Department of Women's and Children's Health, Karolinska Institutet and Karolinska University Hospital, Stockholm, Sweden. ${ }^{5}$ Division of Haematology-Oncology and Stem Cell Transplantation, Children's Hospital, University of Helsinki, Helsinki University Central Hospital, Helsinki, Finland. ${ }^{6}$ Radcliffe Department of Medicine, MRC Weatherall Institute of Molecular Medicine, University of Oxford, Oxford OX39DS, UK. 'Department of Paediatrics and Child Health, Oxford University Hospitals NHS Foundation Trust, and Nuffield Department of Womens and Reproductive Health, University of Oxford, Oxford, UK. ${ }^{8}$ Section of Andrology, Division of Urology, Department of Surgery, University of Utah School of Medicine, Salt Lake City, UT, USA. ${ }^{9}$ Howard Hughes Medical Institute, Department of Oncological Sciences and Huntsman Cancer Institute, University of Utah School of Medicine, Salt Lake City, UT, USA. ${ }^{10}$ Department of Growth and Reproduction, Copenhagen University Hospital (Rigshospitalet), Blegdamsvej 9, 2100 Copenhagen, Denmark. "'Biomedical Sciences, University of Edinburgh, Edinburgh EH8 9XD, UK.

Received: 22 July 2020 Accepted: 6 November 2020

Published online: 04 December 2020

\section{References}

1. Ward E, DeSantis C, Robbins A, Kohler B, Jemal A. Childhood and adolescent cancer statistics, 2014. CA Cancer J Clin. 2014;64(2):83-103.

2. Anderson RA, Mitchell RT, Kelsey TW, Spears N, Telfer EE, Wallace WH. Cancer treatment and gonadal function: experimental and established strategies for fertility preservation in children and young adults. Lancet Diabetes Endocrinol. 2015;3(7):556-67.

3. Skinner R, Mulder RL, Kremer LC, Hudson MM, Constine LS, Bardi E, Boekhout A, Borgmann-Staudt A, Brown MC, Cohn R, Dirksen U, Giwercman A, Ishiguro H, Jahnukainen K, Kenney LB, Loonen JJ, Meacham L, Neggers S, Nussey S, Petersen C, Shnorhavorian M, van den Heuvel-Eibrink MM, van Santen HM, Wallace WH, Green DM. Recommendations for gonadotoxicity surveillance in male childhood, adolescent, and young adult cancer survivors: a report from the International Late Effects of Childhood Cancer Guideline Harmonization Group in collaboration with the PanCareSurFup Consortium. Lancet Oncol. 2017;18(2):e75-e90.

4. Chow EJ, Stratton KL, Leisenring WM, Oeffinger KC, Sklar CA, Donaldson SS, Ginsberg JP, Kenney LB, Levine JM, Robison LL, Shnorhavorian M, Stovall M, Armstrong GT, Green DM. Pregnancy after chemotherapy in male and female survivors of childhood cancer treated between 1970 and 1999: a report from the Childhood Cancer Survivor Study cohort. Lancet Oncol. 2016;17(5):567-76.

5. Green DM, Liu W, Kutteh WH, Ke RW, Shelton KC, Sklar CA, Chemaitilly W, Pui CH, Klosky JL, Spunt SL, Metzger ML, Srivastava D, Ness KK, Robison LL, Hudson MM. Cumulative alkylating agent exposure and semen parameters in adult survivors of childhood cancer: a report from the St Jude Lifetime Cohort Study. Lancet Oncol. 2014;15(11):1215-23.

6. Mitchell RT, Cowan G, Morris KD, Anderson RA, Fraser HM, McKenzie KJ, Wallace WH, Kelnar CJ, Saunders PT, Sharpe RM. Germ cell differentiation in the marmoset (Callithrix jacchus) during fetal and neonatal life closely parallels that in the human. Hum Reprod. 2008;23(12):2755-65.

7. Guo J, Nie X, Giebler M, Mlcochova H, Wang Y, Grow EJ, DonorConnect, Kim R, Tharmalingam M, Matilionyte G, Lindskog C, Carrell DT, Mitchell RT, Goriely A, Hotaling JM, Cairns BR. The dynamic transcriptional cell atlas of testis development during human puberty. Cell Stem Cell 2020;26(2):262276 e264.

8. Valli-Pulaski H, Peters KA, Gassei K, Steimer SR, Sukhwani M, Hermann BP, Dwomor L, David S, Fayomi AP, Munyoki SK, Chu T, Chaudhry R, Cannon GM, Fox PJ, Jaffe TM, Sanfilippo JS, Menke MN, Lunenfeld E, Abofoul-Azab M, Sender LS, Messina J, Klimpel LM, Gosiengfiao Y, Rowell EE, Hsieh MH, Granberg CF, Reddy PP, Sandlow JI, Huleihel M, Orwig KE. Testicular tissue cryopreservation: 8 years of experience from a coordinated network of academic centers. Hum Reprod. 2019;34(6):966-77.

9. Odagiri K, Omura M, Hata M, Aida N, Niwa T, Ogino I, Kigasawa H, Ito S, Adachi M, Inoue T. Treatment outcomes, growth height, and neuroendocrine functions in patients with intracranial germ cell tumors treated with chemoradiation therapy. Int J Radiat Oncol Biol Phys. 2012; 84(3):632-8. 
10. Wallace WH, Shalet SM, Crowne EC, Morris-Jones PH, Gattamaneni HR, Price DA. Gonadal dysfunction due to cis-platinum. Med Pediatr Oncol. 1989; 17(5):409-13.

11. Dasari S, Tchounwou PB. Cisplatin in cancer therapy: molecular mechanisms of action. Eur J Pharmacol. 2014;740:364-78.

12. Oun R, Moussa YE, Wheate NJ. The side effects of platinum-based chemotherapy drugs: a review for chemists. Dalton Trans. 2018;47(19):664553.

13. Hurtado-Gonzalez P, Anderson RA, Macdonald J, van den Driesche $S$, Kilcoyne K, Jorgensen A, McKinnell C, Macpherson S, Sharpe RM, Mitchell RT. Effects of exposure to acetaminophen and ibuprofen on fetal germ cell development in both sexes in rodent and human using multiple experimental systems. Environ Health Perspect. 2018;126(4):047006.

14. van den Driesche S, Macdonald J, Anderson RA, Johnston ZC, Chetty T, Smith LB, McKinnell C, Dean A, Homer NZ, Jorgensen A, Camacho-Moll ME, Sharpe RM, Mitchell RT. Prolonged exposure to acetaminophen reduces testosterone production by the human fetal testis in a xenograft model. Sci Transl Med. 2015;7(288):288ra280.

15. Jorgensen A, Nielsen JE, Perlman S, Lundvall L, Mitchell RT, Juul A, RajpertDe ME. Ex vivo culture of human fetal gonads: manipulation of meiosis signalling by retinoic acid treatment disrupts testis development. Hum Reprod. 2015;30(10):2351-63.

16. Mitchell RT, Saunders PT, Childs AJ, Cassidy-Kojima C, Anderson RA, Wallace WH, Kelnar CJ, Sharpe RM. Xenografting of human fetal testis tissue: a new approach to study fetal testis development and germ cell differentiation. Hum Reprod. 2010;25(10):2405-14.

17. Smart E, Lopes F, Rice S, Nagy B, Anderson RA, Mitchell RT, Spears N. Chemotherapy drugs cyclophosphamide, cisplatin and doxorubicin induce germ cell loss in an in vitro model of the prepubertal testis. Sci Rep. 2018; 8(1):1773.

18. Hermann BP, Sukhwani M, Winkler F, Pascarella JN, Peters KA, Sheng Y, Valli H, Rodriguez M, Ezzelarab M, Dargo G, Peterson K, Masterson K, Ramsey C, Ward T, Lienesch M, Volk A, Cooper DK, Thomson AW, Kiss JE, Penedo MC Schatten GP, Mitalipov S, Orwig KE. Spermatogonial stem cell transplantation into rhesus testes regenerates spermatogenesis producing functional sperm. Cell Stem Cell. 2012;11(5):715-26.

19. Guo J, Grow EJ, Mlcochova H, Maher GJ, Lindskog C, Nie X, Guo Y, Takei Y, Yun J, Cai L, Kim R, Carrell DT, Goriely A, Hotaling JM, Cairns BR. The adult human testis transcriptional cell atlas. Cell Res. 2018; 28(12):1141-57.

20. Hermann BP, Cheng K, Singh A, Roa-De La Cruz L, Mutoji KN, Chen IC, Gildersleeve H, Lehle JD, Mayo M, Westernstroer B, Law NC, Oatley MJ, Velte EK, Niedenberger BA, Fritze D, Silber S, Geyer CB, Oatley JM, McCarrey JR. The mammalian spermatogenesis single-cell transcriptome, from spermatogonial stem cells to spermatids. Cell Rep 2018;25(6):1650-1667 e1658.

21. Picton HM, Wyns C, Anderson RA, Goossens E, Jahnukainen K, Kliesch S, Mitchell RT, Pennings G, Rives N, Tournaye $H$, van Pelt AM, Eichenlaub-Ritter U, Schlatt S. Diseases ETFOFPIS. A European perspective on testicular tissue cryopreservation for fertility preservation in prepubertal and adolescent boys. Hum Reprod. 2015;30(11):2463-75.

22. Kilcoyne KR, Mitchell RT. Fertility preservation: testicular transplantation for fertility preservation: clinical potential and current challenges. Reproduction. 2019;158(5):F1-F14.

23. Carrieri C, Comazzetto S, Grover A, Morgan M, Buness A, Nerlov C, O'Carroll D. A transit-amplifying population underpins the efficient regenerative capacity of the testis. J Exp Med. 2017;214(6):1631-41.

24. Robison LL, Armstrong GT, Boice JD, Chow EJ, Davies SM, Donaldson SS, Green DM, Hammond S, Meadows AT, Mertens AC, Mulvihill JJ, Nathan PC, Neglia JP, Packer RJ, Rajaraman P, Sklar CA, Stovall M, Strong LC, Yasui Y, Zeltzer LK. The Childhood Cancer Survivor Study: a National Cancer Institute-supported resource for outcome and intervention research. J Clin Oncol. 2009;27(14):2308-18.

25. Wasilewski-Masker K, Seidel KD, Leisenring W, Mertens AC, Shnorhavorian M, Ritenour CW, Stovall M, Green DM, Sklar CA, Armstrong GT, Robison LL, Meacham LR. Male infertility in long-term survivors of pediatric cancer: a report from the childhood cancer survivor study. J Cancer Surviv. 2014;8(3):437-47.

26. Allen CM, Lopes F, Mitchell RT, Spears N. Comparative gonadotoxicity of the chemotherapy drugs cisplatin and carboplatin on prepubertal mouse gonads. Mol Hum Reprod. 2020;26:129-140. https://doi.org/10.1093/molehr/ gaaa008.
27. Viviani S, Santoro A, Ragni G, Bonfante V, Bestetti O, Bonadonna G. Gonadal toxicity after combination chemotherapy for Hodgkin's disease. Comparative results of MOPP vs ABVD. Eur J Cancer Clin Oncol. 1985;21(5): $601-5$.

28. Gaskell TL, Esnal A, Robinson LL, Anderson RA, Saunders PT. Immunohistochemical profiling of germ cells within the human feta testis: identification of three subpopulations. Biol Reprod. 2004;71(6): 2012-21.

29. Köhler C, Oppelt P, Favero G, Morgenstern B, Runnebaum I, Tsunoda A, Schmittel A, Schneider A, Mueller M, Marnitz S. How much platinum passes the placental barrier? Analysis of platinum applications in 21 patients with cervical cancer during pregnancy. Am J Obstet Gynecol. 2015;213(2):206 e201-205.

30. Calsteren KV, Verbesselt R, Devlieger R, De Catte L, Chai DC, Van Bree R, Heyns L, Beijnen J, Demarsin S, de Bruijn E, de Hoon J, Amant F. Transplacental transfer of paclitaxel, docetaxel, carboplatin, and trastuzumab in a baboon model. Int J Gynecol Cancer. 2010;20(9):1456-64.

31. Pascual MJ, Macias RI, Garcia-Del-Pozo J, Serrano MA, Marin JJ. Enhanced efficiency of the placental barrier to cisplatin through binding to glycocholic acid. Anticancer Res. 2001;21(4a):2703-7.

32. Prouillac C, Lecoeur $\mathrm{S}$. The role of the placenta in fetal exposure to xenobiotics: importance of membrane transporters and human models for transfer studies. Drug Metab Dispos. 2010;38(10):1623-35.

33. Safaei R, Howell SB. Copper transporters regulate the cellular pharmacology and sensitivity to Pt drugs. Crit Rev Oncol Hematol. 2005;53(1):13-23.

34. Welsh M, Saunders PT, Fisken M, Scott HM, Hutchison GR, Smith LB, Sharpe RM. Identification in rats of a programming window for reproductive tract masculinization, disruption of which leads to hypospadias and cryptorchidism. J Clin Invest. 2008;118(4):1479-90.

35. Kilcoyne KR, Mitchell RT. Effect of environmental and pharmaceutical exposures on fetal testis development and function: a systematic review of human experimental data. Hum Reprod Update. 2019;25(4):397-421.

36. van den Driesche S, McKinnell C, Calarrao A, Kennedy L, Hutchison GR, Hrabalkova L, Jobling MS, Macpherson S, Anderson RA, Sharpe RM, Mitchell RT. Comparative effects of di(n-butyl) phthalate exposure on fetal germ cell development in the rat and in human fetal testis xenografts. Environ Health Perspect. 2015:123(3):223-30

37. Mitchell RT, Childs AJ, Anderson RA, van den Driesche S, Saunders PT, McKinnell C, Wallace WH, Kelnar CJ, Sharpe RM. Do phthalates affect steroidogenesis by the human fetal testis? Exposure of human fetal testis xenografts to di-n-butyl phthalate. J Clin Endocrinol Metab. 2012;97(3):E341-8.

38. Howard SR, Dunkel L. Management of hypogonadism from birth to adolescence. Best Pract Res Clin Endocrinol Metab. 2018;32(4):355-72.

\section{Publisher's Note}

Springer Nature remains neutral with regard to jurisdictional claims in published maps and institutional affiliations.

Ready to submit your research? Choose BMC and benefit from:

- fast, convenient online submission

- thorough peer review by experienced researchers in your field

- rapid publication on acceptance

- support for research data, including large and complex data types

- gold Open Access which fosters wider collaboration and increased citations

- maximum visibility for your research: over $100 \mathrm{M}$ website views per year

At $\mathrm{BMC}$, research is always in progress.

Learn more biomedcentral.com/submissions 